\title{
RISK MANAGEMENT IN PUBLIC PROCUREMENT PROCESS. PARTICULARITIES AND SOLUTIONS FOR OPTIMIZING PUBLIC PROCUREMENT IN ROMANIA IN THE CONTEXT OF EMERGENCY CAUSED BY THE COVID- 19 CRISIS
}

\author{
Costel Ceocea \\ „Vasile Alecsandri” University of Bacău, Romania \\ cceocea@sifm.ro \\ Raluca Alexandra Ceocea \\ „Gh. Asachi” University of Iași, Romania \\ raluca.ceocea@gmail.com \\ Adrian Vatamaniuc \\ „Gh. Asachi” University of Iași, Romania \\ adrian.vatamaniuc@gmail.com \\ Vasile Mihălaș \\ „Vasile Alecsandri” University of Bacău, Romania \\ mihalas2018@gmail.com
}

\begin{abstract}
Public procurement involves adequate risk management, specific to the procurement portfolio established at the level of the organization. In order to achieve the proposed objectives, in accordance with the regulated framework established at the level of public institutions from Romania, decisions made at the level of contracting authorities must be based on risk management tools and mechanisms. These tools and mechanisms are defined on the basis of analyses of public procurement processes, carried out in compliance with the legal framework applicable at both European and national level. The new context created at the level of the contracting authorities in Romania, with the onset of the COVID-19 crisis, forced the management factors to adopt emergency decisions, to manage new risks and to implement rapid changes in public procurement processes, in the context of high uncertainty. This paper aims at analyzing the way decisions are made at the level of contracting authorities in Romania, in order to identify specific risk management mechanisms, based on the assessment and anticipation of risks related to public procurement organized in an matter of emergency.
\end{abstract}

\section{Keywords}

Romania; public procurement management; risk management; risk factors; change management; decision-making; anticipation; emergency; COVID 19

\section{JEL Classification}

D81; D73; H57

\section{Introduction}

The purpose of Public Procurement is to award contracts for supply, service or works under conditions of economic and social efficiency ${ }^{1}$, in accordance with the principles and procedures set by the applicable legal framework of these activities, to economic operators qualified for the optimal execution of such contracts.

\footnotetext{
${ }^{1}$ Article 2 (2) from Law no 98/2016 on public procurement
} 
The award of these public procurement contracts shall ensure the necessary resources to carry out the activities and achieve the objectives set at the level of public institutions, which aim to achieve/satisfy a general interest. From the perspective of analyzing the field of action, but also the scope, some experts like (Becq, 2006) points to the trend towards unifying the legislative framework, while others (Harink, 1999) points out that the field of public procurement comprises a set of strategies and procedures whose purpose is to transfer goods to achieve the ultimate objectives.

The current public management that has been influenced by the current New Public Management since the 80 enforces public factors to abandon outdated methods, specific to a traditional bureaucracy based mainly on administrative decisions and to adopts and adopt complex managerial positions built on rational, scientifically grounded decisions based on knowledge and innovation.

Accepting the functional definition ${ }^{2}$ of public management proposed by Imbrescu (2010), we see the need for decisions taken in the public sector to be rationally substantiated so that the actions taken to ensure optimal results in ensuring the provision of public services by the organization.

Modern, goal-based management draw attention to the idea of streamlining the use of organizational resources, (Noordegraaf, 2015) in the context of coordinating social efforts so that objectives can be achieved and public needs met.

In other words, the concept of public governance, oriented towards the management, coordination and use of institutional commitments (Grossi \& Steccolini, 2014) requires the adoption of rational decisions, based on the development of processes with a high level of complexity (Adroniceanu, 1999) which aims at selecting a decision from the set of identified alternatives which exerts influences at individual, systemic or societal level.

Public procurement management manages the processes specific to the first stage of the process of ensuring and managing the resources necessary to carry out public administration activities. In this context, Public Procurement Management, a component of Public Management, is responsible for carrying out the processes of quantifying the „objective need”, transforming it into an „objective necessity” and then satisfying the latter optimally, through the contract of public procurement, reason for which the decisions adopted within the public procurement management processes have a major impact on the future decisions that can be adopted, respectively on the results of the administrative activity related to the public organizations.

Although risk and risk management are generally seen as a function assigned to certain categories of specialists, achieving the objectives set at the level of public institutions requires the adoption of a strategy based on risk management measures and mechanisms, by involving all officials responsible for both management processes as well as the execution processes within the public organization, oriented towards the adoption of decisions that have the capacity to diminish the effects of some events that can negatively affect the degree of achievement of these objectives and implicitly the beneficiaries of these decisions: citizens.

Therefore, in order to ensure the achievement of the institutional objectives set at the level of contracting authorities, it is necessary to adopt an adequate risk management, which should be the basis for decisions related to public procurement processes to ensure the optimal allocation of the portfolio of public procurement contracts. Through which the products, services or works are provided, at the qualitative, quantitative level

\footnotetext{
${ }^{2}$ „The set of management processes (relationships) existing between the components of the administrative system, through which, in public power, laws are enforced (by organization or direct execution) and / or are planned, organized, led coordinates, manages and controls the activities involved performing services that satisfy the general public interest" (Imbrescu, 2010)
} 
and at the time imposed by the objective needs and necessities established at the level of the public organization.

\section{The risk and public procurement processes}

\subsection{The context of management risk specific to contracting authorities}

The definition of risk is the subject of numerous studies, each specialist seeking to capture only one side or all of its sides and dimensions. As far as we are concerned, in relation to the purpose of this paper, we consider that the approach to risk in relation to the uncertainty and the effects on the proposed objectives (Vișoiu \& Rusu, 2010, p. 23), allows the establishment of a coherent analysis framework.

Risk in public procurement cannot be avoided, as it exists at any time or stage of the public procurement process, that is why public procurement management must carry out concrete, operational activities at all levels of the contracting authority in order to optimally understand and manage these risks.

A risk approach in public procurement processes must be based on an adaptation of the concepts and techniques of risk developed and applied at the level of all organizations in the light of the regulatory framework applicable to public organizations and the specific limitations imposed on contracting authorities.

Within the process applied at the level of the contracting authority, for the implementation of risk management in public procurement, it will be considered both the establishment of the context of the public procurement process carried out at the organization level and the assessment and treatment of risks specific to public procurement processes.

Establishing the organizational context applicable to risk management in public procurement is done taking into account:

a) Internal and external parameters to be taken into account for the management of risks specific to public procurement processes (both at the level of the contracting authority and at the level of potential bidders)

b) The objectives set at the level of the planned public procurement portfolio

c) The architecture of the organizational chart of the personnel involved in the public procurement processes at the level of the organization

d) Identifying and analyzing the direct beneficiaries within the organization who will be responsible for receiving and / or using the products, services or works to be purchased, including their expectations regarding the object and manner of future public procurement contracts.

e) The legal and normative framework applicable in the area of public procurement and, as the case may be, the subject of future contracts for public procurement.

The process of assessing the risks specific to public procurement takes place in the following stages:

Risk identification - as a process aimed at identifying, recognizing and estimating all potential events or situations that, if they occur, will affect the fulfillment of the objectives set at the level of the public procurement portfolio of the organization.

The elements to be addressed at each defined risk level are:

$>$ Source / cause of risk - as a situation that causes the identified event

$>$ The event - as an action that can occur and that will be related to the source of the risk.

$>$ The impact - as a result of the event, a natural consequence of the occurrence of the risk

$>$ Time and place - as positioning in time and space of the identified event 
Risk identification ,is the first and most important phase of the risk management process, which consists in identifying the potential hazards that exist within the entity" (Florea-Ianc, 2010)

Following the analysis of the public procurement process indicated by Public Procurement Law no 98/2016 respectively by the Norms of application of this law $^{3} 2$ the risk portfolio identifiable at the level of most contracting authorities can be grouped as follows:

\section{Table 1}

\begin{tabular}{|c|c|c|}
\hline $\begin{array}{l}\text { Risk } \\
\text { category }\end{array}$ & Risk group & Types of risks \\
\hline \multirow{19}{*}{$\begin{array}{l}\text { Context } \\
\text { risks }\end{array}$} & \multirow{6}{*}{$\begin{array}{l}\text { Economic } \\
\text { risks }\end{array}$} & Risks associated with working conditions \\
\hline & & Risks related to inflation and / or price stability \\
\hline & & $\begin{array}{l}\text { Risks related to the activity of the competitors in the } \\
\text { market to which the public procurement contract is } \\
\text { addressed }\end{array}$ \\
\hline & & $\begin{array}{l}\text { Risks related to the financial market, the fiscal } \\
\text { environment and the ability to finance the activities of } \\
\text { market operators }\end{array}$ \\
\hline & & Currency risk \\
\hline & & $\begin{array}{l}\text { Risks associated with the financing capacity of } \\
\text { contractors }\end{array}$ \\
\hline & \multirow{7}{*}{$\begin{array}{l}\text { Socio- } \\
\text { cultural risks }\end{array}$} & $\begin{array}{l}\text { The risk of fraud, corruption, theft, professional } \\
\text { negligence }\end{array}$ \\
\hline & & Risks associated with media campaigns \\
\hline & & $\begin{array}{l}\text { Changing the behavior of end users of the object of } \\
\text { acquisition }\end{array}$ \\
\hline & & $\begin{array}{l}\text { Power positions of entities acting on producers / } \\
\text { importers }\end{array}$ \\
\hline & & $\begin{array}{l}\text { Deficiencies in the expertise in the relevant sector of } \\
\text { activity in relation to the object of the PA contract }\end{array}$ \\
\hline & & Lack of capacity of teams involved in PA processes \\
\hline & & $\begin{array}{l}\text { Lack of leadership skills of decision makers involved in } \\
\text { the PA process }\end{array}$ \\
\hline & \multirow{4}{*}{$\begin{array}{l}\text { Political and } \\
\text { legal risks }\end{array}$} & Political and administrative risks \\
\hline & & $\begin{array}{l}\text { Risks associated with states of local / regional / national } \\
\text { political instability }\end{array}$ \\
\hline & & Risks associated with trade sanctions / restrictions \\
\hline & & Risks associated with gaps or legislative ambiguities \\
\hline & \multirow{2}{*}{$\begin{array}{l}\text { Environment } \\
\text { al risks }\end{array}$} & $\begin{array}{l}\text { Risks associated with climatic factors: storms, floods, } \\
\text { landslides, extreme weather events }\end{array}$ \\
\hline & & $\begin{array}{l}\text { Risks associated with events / accidents with local / } \\
\text { regional impact: triggering of major fires, major } \\
\text { alterations of soil characteristics, etc. }\end{array}$ \\
\hline
\end{tabular}

\footnotetext{
${ }^{3}$ The methodological norms for applying the provisions regarding the award of the public procurement contract / framework agreement from Law no. 98/2016 on public procurement published by Government Decision no. 395/2016
} 


\begin{tabular}{|c|c|c|}
\hline & & $\begin{array}{l}\text { Risks associated with the onset of diseases (epidemics / } \\
\text { pandemics) affecting human, animal or plant health, } \\
\text { with major economic and social impact }\end{array}$ \\
\hline \multirow{8}{*}{$\begin{array}{l}\text { Portfolio } \\
\text { risks }\end{array}$} & \multirow{2}{*}{$\begin{array}{l}\text { Risks } \\
\text { regarding the } \\
\text { structuring } \\
\text { of the } \\
\text { procurement } \\
\text { portfolio }\end{array}$} & $\begin{array}{l}\text { Risks associated with the process of quantifying the } \\
\text { need / necessity }\end{array}$ \\
\hline & & $\begin{array}{l}\text { Risks associated with the process of establishing the } \\
\text { estimated value and allocating the financial resources } \\
\text { related to public procurement contracts }\end{array}$ \\
\hline & \multirow{3}{*}{$\begin{array}{l}\text { Risks } \\
\text { associated } \\
\text { with the } \\
\text { capacity of } \\
\text { the } \\
\text { contracting } \\
\text { authority }\end{array}$} & $\begin{array}{l}\text { Risks associated with the training of human resources } \\
\text { involved in public procurement processes }\end{array}$ \\
\hline & & $\begin{array}{l}\text { Risks associated with the lack of skills needed to plan } \\
\text { and manage the public procurement portfolio }\end{array}$ \\
\hline & & $\begin{array}{l}\text { Risks associated with the ability to plan and allocate } \\
\text { time resources related to public procurement processes }\end{array}$ \\
\hline & \multirow{3}{*}{$\begin{array}{l}\text { Risks of } \\
\text { using } \\
\text { uncompetitiv } \\
\text { e purchasing } \\
\text { methods }\end{array}$} & $\begin{array}{l}\text { Risks regarding the division / structuring of public } \\
\text { procurement contracts in order to avoid awarding } \\
\text { contracts through competitive procedures }\end{array}$ \\
\hline & & $\begin{array}{l}\text { Risks regarding the violation of the principles } \\
\text { legislation applicable to public procurement / object of } \\
\text { the contract in the process of planning / structuring the } \\
\text { public procurement portfolio }\end{array}$ \\
\hline & & $\begin{array}{l}\text { Risk of misuse of exceptions or emergencies for public } \\
\text { procurement portfolio planning }\end{array}$ \\
\hline \multirow{15}{*}{$\begin{array}{l}\text { Process } \\
\text { risks }\end{array}$} & \multirow{5}{*}{ Internal risks } & Contractual risks \\
\hline & & Financial risks \\
\hline & & $\begin{array}{l}\text { Personnel risks (availability, level of education, } \\
\text { competence of staff involved in public procurement } \\
\text { processes, conflicts, etc.) }\end{array}$ \\
\hline & & Risks regarding the organizational system \\
\hline & & Risks regarding data and information resources \\
\hline & \multirow{5}{*}{$\begin{array}{l}\text { Risks related } \\
\text { to the } \\
\text { selected } \\
\text { award } \\
\text { procedure }\end{array}$} & $\begin{array}{l}\text { Risks regarding tender documents (definition of } \\
\text { technical specifications, contractual clauses, conditions } \\
\text { of participation) }\end{array}$ \\
\hline & & $\begin{array}{l}\text { Risks in ensuring transparency and equal treatment in } \\
\text { the award procedure }\end{array}$ \\
\hline & & Risk associated with bid evaluation \\
\hline & & $\begin{array}{l}\text { Risks associated with the award and conclusion of the } \\
\text { public procurement contract }\end{array}$ \\
\hline & & $\begin{array}{l}\text { Risks associated with the execution of public } \\
\text { procurement contracts }\end{array}$ \\
\hline & \multirow{3}{*}{$\begin{array}{l}\text { Technical } \\
\text { risks }\end{array}$} & $\begin{array}{l}\text { Risks associated with the development and } \\
\text { technological advancement and innovation in the field } \\
\text { of the object of the contract }\end{array}$ \\
\hline & & Risks associated with design / design errors \\
\hline & & $\begin{array}{l}\text { Risks associated with technical failures / unavailability } \\
\text { / incompatibilities }\end{array}$ \\
\hline & \multirow{2}{*}{$\begin{array}{l}\text { Commercial } \\
\text { risks }\end{array}$} & $\begin{array}{l}\text { Risks associated with the performance (technical / } \\
\text { logistical / organizational) of the contractor }\end{array}$ \\
\hline & & Internal commercial risks (working capital insurance) \\
\hline
\end{tabular}




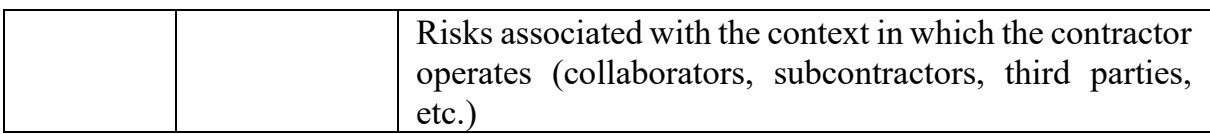

Source: Authors, based on their own analyzes and ANAP recommendations (Public Procurement Guide available at https://achizitiipublice.gov.ro/home)

Risk analysis - as a process oriented towards understanding the risk, its assessment, providing input data for structuring the identified risk assessment processes. In this process, attention will be paid to detecting the public procurement process directly affected by the identified event the real limits of the elements of each identified event and the possible relationships of this event with other probable events, following the consequences on one or more objectives related to the public procurement portfolio. Both negative and positive consequences will be analyzed, according to the precautionary principle (by maximizing negative effects and minimizing positive effects).

According Ayyub, Bilal M., risk analysis ,is the technical and scientific process for understanding the nature of the risk and determining the level of risk by examining the basic risk components or elements". (Ayyub, 2014)

Risk assessment - as a management process based on comparing the level of risk identified with the tolerance criteria of the organization in order to establish initial priorities and adopt the best strategy to address these risks. This process is based on specific risk assessment methods and techniques, adopted at the level of each contracting authority, such as the probability assessment scale, the impact assessment scale or the risk exposure assessment scale.

By reference to the content of the standard ISO 31010, risk assessment ,involves comparing the estimated risk levels with the criteria defined in the context in which it was established, to determine the importance of the level and type of risk" (International Organization for Standardization, 2009).

From the point of view of the tools used to manage the risk management processes::

a) for the process of identification and analysis of risks in the field of public procurement, we consider it useful the use of risk assessment sheets (risk scenarios) that deal in detail, for each event identified at least:

$\checkmark$ description of its sources/causes, supporting elements and triggering elements.

$\checkmark$ description of the spatial dimension of the event,

$\checkmark$ temporary positioning and its duration

$\checkmark$ the potential evolution of the event over time,

$\checkmark$ its ability to trigger other subsequent / collateral events that have the potential to influence the effects of the initially identified event or to generate new effects;

$\checkmark$ the public procurement process/processes affected and the impact of the event on it

$\checkmark$ estimating the probability of occurrence of the event as well as other subsequent/collateral events

$\checkmark$ uncertainties associated with the event analysis process

b) For the risk assessment process specific to public procurement, we consider it useful the use, as a quantitative method, a risk matrix, prepared separately for each identified risk category, which will highlight the factors which influences the occurrence of the event, analysis of consequences, estimation of the probability of occurrence of the event, the uncertainties associated with the risk analysis process. 
As tools for formalizing this stage of the risk management process, we consider as appropriate those recommended by the General Secretariat of the Government through the package of documents specific to the Internal Management Control System ${ }^{4}$.

We are of the opinion that the tools used in risk management processes as well as the degree of standardization and clarity of information highlighted in these tools can influence the level of quality of the decision-making process adopted at the organization level, with a negative impact on risk treatment.

Ensuring in this way a unitary concept of risk management, at the level of certain categories of contracting authorities, will allow the trans-organizational consolidation of the results of risk assessments and their quantification at sectoral level (eg hospitals, local public authorities, etc. ) for the purpose of identifying and adopting measures at national/regional level (legislative/administrative) with a favorable impact on reducing the probability/intensity of certain risk categories, common to certain categories of contracting authorities.

All these tools for identification and analysis as well as risk assessment methods in the field of public procurement provide input for the risk treatment stage.

Risk treatment - as a process aimed at identifying the range of options and making the best decisions to address the identified risks. The decisions taken can be oriented towards:

$\checkmark$ Risk avoidance - through decisions not to initiate or continue the public procurement process

$\checkmark$ Removal /isolation of the risk (or its source)

$\checkmark$ Changing the nature or degree of probablity of the risk

$\checkmark \quad$ Mitigation of the consequences of risk

$\checkmark$ Transfer or risk sharing to the contractor (or other entity involved in the public procurement process)

$\checkmark$ The retention / acceptance of the risk in the identified form

The selection of the best option is made on the basis of an analysis based on the balance between the effort required by the application of proposed decision (material, human, temporary, financial, etc.) and the institutional benefits, obtained in this way, by the contracting authority, subject to compliance with the applicable legal framework in the field of public procurement.

We consider that an option that presents several alleged advantages, with a favorable impact on the management of the contracting authority, but which violates the legal framework applicable to public procurement or the principles underlying the award of public procurement contracts, does not contribute to the purpose of this legal framework defined by article 2 (1) of Law no. 98/2016 and is likely to seriously affect the trust, fairness and impartiality in the public procurement system, respectively the health of the competitive framework that ensures the best results on the market for allocated public funds, which is why we consider that this option cannot be part of the risk management process.

Also during this stage, attention will be paid to the identification of the parameters of residual risks, considered as risks that persist even after the risk treatment stage, on which occasion the opportunity to initiate additional processes to treat these residual risks can be analyzed.

Methods that can be used in public procurement-specific risk management activities should primarily be those based on risk scenarios and those based on event-ordering and to use input data both from similar procurement processes carried out at the level

4 „Methodology of Risk Management” published by the General Secretariat of the Government on https://sgg.gov.ro/new/metodologie-scim/

${ }_{5}^{5}$ Article 2 (1) from Public Procurement Law no 98/2016: ,, The purpose of this law is to ensure the necessary legal framework to achieve the purchase of goods, services and works in conditions of economic and social efficiency" 
of other contracting authorities and from similar processes carried out at the level of the contracting authority (generated by „ex-post” analyzes of the procurement processes carried out).

Based on the risk sheets, the risk matrix and the risk management plan, a risk register will be drawn up at the level of the contracting authority, as a risk management tool, provided by the law framework ${ }^{6}$, in which, for each identified risk, at least the following information will be highlighted:

$\checkmark$ date of risk identification

$\checkmark$ source of risk

$\checkmark$ risk description

$\checkmark$ consequence/ consequences

$\checkmark$ inherent risk by indicating the probability, impact and exposure to risk

$\checkmark$ strategy adopted at organizational level

$\checkmark$ residual risk by indicating the probability, impact and exposure to the residual risk

$\checkmark \quad$ estimated time for impact

$\checkmark$ current status of the highlighted risk

As highlighted by the general theory of management, the ability to manage risk management processes is directly influenced by the professional experience of people involved in the activities of identification, analysis, assessment and treatment of risks, which is why we consider that the teams selected by the heads of the contracting authorities must be made up of specialists from all sectors of activity within the institution, who have sufficient experience in this field.

\section{Management of public procurement risks in the context of the emergency triggered by the COVID-19 crisis}

\subsection{Decision-making context at the level of contracting authorities with an active role in combating the spread of COVID-19 Coronavirus and managing its effects}

After identification in WUHAN (China) the outbreak of the novel coronavirus COVID19 (December 2019), on January 30, 2020 The World Health Organization (WHO) stated that this event is likely to pose a risk to public health in the other states, having the potential to spread globally.

In February 2020, both the European Center for Disease Prevention and Control (CEPCB) and other relevant organizations in the Member States sent messages about the need to closely monitor the spread of the new Coronavirus COVID-19 in order to provide risk assessments involved of this crisis as well as to initiate plans of measures to respond to these risks.

Subsequently, on March 11, 2020, the World Health Organization officially declared a state of pandemic and on March 13, 2020, declared Europe as an active center of this pandemic.

Until these moments, data circulating in the public space confirmed that the international epidemiological situation caused by the spread of novel Coronavirus COVID-19 affected more then 150 countries, infecting over 160,000 people and causing over 5,500 deaths.

\footnotetext{
${ }^{6}$ Article 5 (4) of the Order of the General Secretariat of the Government no. 600/2016 on the approval of the "Code of internal managerial control of public entities"
} 
In Romania, by the Decree no. 195 of 16 March 2020, the state of emergency was established by which special emergency measures were adopted in the field of public order, the economic field, the health field, the field of work and social protection, the field of justice and the field of foreign affairs.

Therefore, we find that data on the announcement of the COVID 19 epidemic event have been transmitted in the public space since January 2020, when the relevant public institutions were responsible for preparing the risk scenarios triggered by the epidemic and initiating action plans that should be undertaken in order to control the spread of this virus in order to reduce its impact on the population.

At that time, according to the function of periodic revisions of risk plans, it was necessary to initiate the process of identification-analysis-assessment-treatment of risks caused by the spread of the new Coronavirus COVID19 in Romania, on which occasion the organizational context applicable to this process had to be taken into account, in relation to the type of public institution at which this process should have been initiated as well as the role it would have played in the actions to prevent the spread of the virus and managing its consequences.

Thus, analyzing from the perspective of the organizational context of some hospital units or institutions actively involved in the implementation of the action plans imposed by triggering the state of emergency, we can appreciate that it was necessary to initiate review processes at the level of public procurement management/updating the risk registers and implicitly the action plans adopted as a consequence

\subsection{Risk management in the field of public procurement of personal protective equipment, in the context of COVID-19.}

Existing protocols in the health environment as well as operational procedures implemented at the level of institutions responsible for emergency management (e.g. Romanian General Inspectorate for Emergency Situations), applicable in case of epidemic situations, indicated that in case of a pandemic situation, the need for personal protective equipment and disinfectants is considerably higher than in normal working situations, which is why the attention of public decision-makers should be given priority to the provision of stocks of such products an affordable price.

In the following, for simplification, we will approach a risk analysis only from the perspective of the process of purchasing surgical masks, a product that was in great demand during the state of emergency and was used in varying amounts by all public institutions, which played an active role in measures taken to control the spread of COVID19 Coronavirus and to manage the consequences.

In relation to the purchase of this product, the objectives that could be influenced by the risks generated by the COVID crisis are:

O1. Identifying / contracting suppliers who have the capacity to fulfill the public procurement contract

O2. Delivery of products on time

O3 Purchasing products at an affordable price

Following the analysis and assessment of the risks specific to public procurement (Table 1), using the tools recommended by the General Secretariat of the Government ${ }^{7}$, for public procurement processes for the provision of personal protective equipment in the context of the COVID crisis, the following risks have been shown to have a high probability and impact on the achievement of one or more of the above objectives:

7 „Risk Management Methodology” published by the General Secretariat of the government at https://sgg.gov.ro/new/metodologie-scim/ 
Table 2

\begin{tabular}{|c|c|c|c|}
\hline $\begin{array}{c}\text { Risk } \\
\text { category }\end{array}$ & Risk group & Identified risks & $\begin{array}{c}\text { Influenced } \\
\text { target }\end{array}$ \\
\hline \multirow[b]{2}{*}{$\begin{array}{l}\text { Context } \\
\text { risks }\end{array}$} & \multirow[b]{2}{*}{$\begin{array}{l}\text { R.1.Economi } \\
\text { c risks }\end{array}$} & $\begin{array}{l}\text { R.1.1. - Risks related to inflation and / or } \\
\text { price stability }\end{array}$ & $\mathrm{O} 3$ \\
\hline & & $\begin{array}{l}\text { R.1.2.- Risks related to the activity of the } \\
\text { competitors in the market to which the } \\
\text { public procurement contract is addressed }\end{array}$ & $\mathrm{O} 1+\mathrm{O} 2$ \\
\hline $\begin{array}{l}\text { Portfolio } \\
\text { risks }\end{array}$ & $\begin{array}{l}\text { R.2.- Risks } \\
\text { regarding the } \\
\text { structuring } \\
\text { of the } \\
\text { procurement } \\
\text { portfolio }\end{array}$ & $\begin{array}{l}\text { R.2.1.- Risks associated with the process } \\
\text { of establishing the estimated value and } \\
\text { allocating financial resources related to } \\
\text { public procurement contracts }\end{array}$ & $\mathrm{O} 3$ \\
\hline \multirow{4}{*}{$\begin{array}{l}\text { Process } \\
\text { risks }\end{array}$} & \multirow{2}{*}{$\begin{array}{l}\text { R.3. Internal } \\
\text { risks }\end{array}$} & R.3.1. -Contractual risks & $\mathrm{O} 2$ \\
\hline & & R.3.2.- Financial risks & $\mathrm{O} 3$ \\
\hline & \multirow{2}{*}{$\begin{array}{l}\text { R.4. } \\
\text { Commercial } \\
\text { risks }\end{array}$} & $\begin{array}{l}\text { R.4.1.- Risks associated with the context } \\
\text { in which the contractor operates } \\
\text { (suppliers, collaborators, subcontractors, } \\
\text { third parties, etc.) }\end{array}$ & $\mathrm{O} 2$ \\
\hline & & $\begin{array}{l}\text { R.4.2.- Risks associated with the timely } \\
\text { execution of public procurement contracts }\end{array}$ & $\mathrm{O} 2$ \\
\hline
\end{tabular}

Source: Authors.

Before presenting an approach on the treatment of these specific risks, as a reference element, we consider relevant the presentation of the table of procurement processes for surgical masks carried out through the SEAP catalog, between January and April 2020 , compared to those carried out in the same period last year.

Table 3

\begin{tabular}{|c|c|c|c|c|c|c|c|c|}
\cline { 2 - 9 } \multicolumn{1}{c|}{} & \multicolumn{2}{c|}{ January } & \multicolumn{2}{c|}{ February } & \multicolumn{2}{c|}{ March } & \multicolumn{2}{c|}{ April } \\
\cline { 2 - 9 } \multicolumn{1}{c|}{} & $\mathbf{2 0 1 9}$ & $\mathbf{2 0 2 0}$ & $\mathbf{2 0 1 9}$ & $\mathbf{2 0 2 0}$ & $\mathbf{2 0 1 9}$ & $\mathbf{2 0 2 0}$ & $\mathbf{2 0 1 9}$ & $\mathbf{2 0 2 0}$ \\
\hline Acquisitions & 44 & 17 & 32 & 78 & 11 & 251 & 9 & 263 \\
\hline $\begin{array}{c}\text { Quantity } \\
\text { (pcs) }\end{array}$ & 230.750 & 60.990 & 138.350 & 398.550 & 51.400 & 1.376 .280 & 25.450 & 1.816 .527 \\
\hline $\begin{array}{c}\text { Average unit } \\
\text { price (RON } \\
\text { /pc) }\end{array}$ & 0,09 & 0,17 & 0,08 & 1,83 & 0,08 & 3,75 & 0,08 & 2,73 \\
\hline \multicolumn{3}{c|}{ Source: SEAP- direct acquisitions extract http://e-licitatie.ro/pub } \\
\hline
\end{tabular}

The following information provided by the Romanian Public Procurement System should also be noted as a reference:

$>$ the number of purchases of surgical masks initiated by contracting authorities from using SEAP and rejected by bidders, in January-April 2020, was approx. 450 acquisitions, representing approx. $74 \%$ of total purchases of these products completed in the same period (609 transactions);

$>$ between January-February 2020, within the SEAP, no competitive procedure was initiated (open or simplified tender) for the purchase of surgical masks 
and which could have been awarded until the end of April 2020.

$>$ the first competitive procedures initiated by SEAP and aimed at the acquisition of surgical masks were launched in the second half of March 2020, with a schedule of completion, award and contracting beginning May 2020.

In detail, it is found that the number of contracts for the supply of surgical masks has increased, compared to the previous year, by approx. 2.5 times in February, 22 times in March 2020 and 30 times in April, which is mainly influenced by the measures adopted by public authorities in the context of the crisis of COVID-19. It should be noted that January 2020 does not provide a picture of these purchases that would betray the adoption of early measures to ensure preventive stocks of these products.

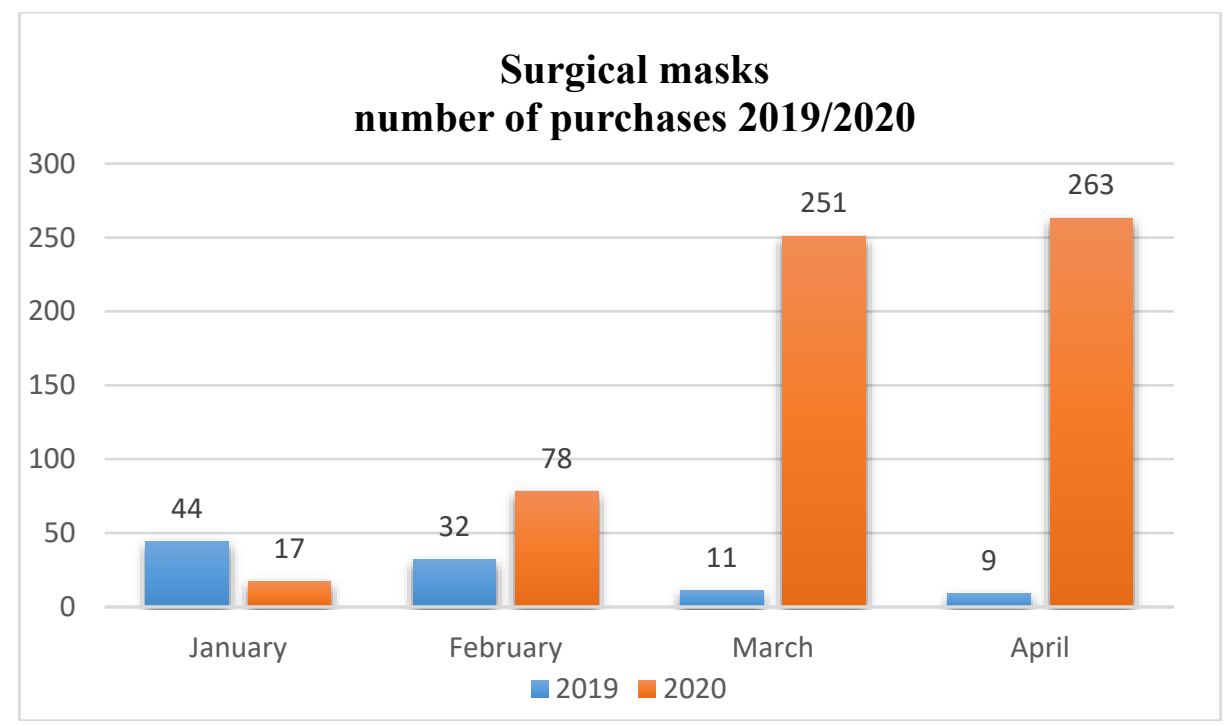

\section{Chart 1 2019/2020 comparative analysis of the number of public procurement contracts concluded for the purchase of surgical masks \\ Source: Romania's electronic public procurement system (SEAP)}

In the same trend, the number of surgical masks purchased increased compared to the previous year, 2.9 times in February 2020, 26 times in March 2020 and 71 times in April 2020. In the same note, it is noted that the number of surgical masks purchased in January 2020 does not seem to be influenced by the messages launched in the public space by the World Health Organization or European Centre for Disease Prevention and Control. 


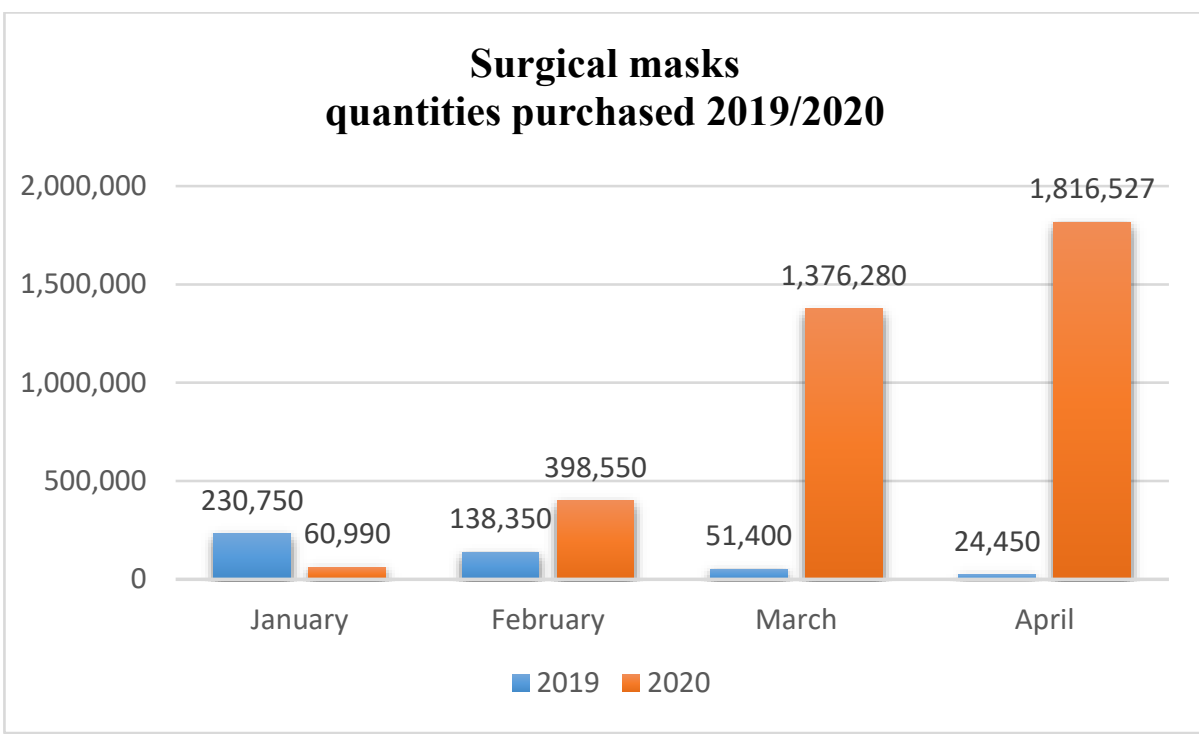

\section{Chart 2 Comparative analysis 2019/2020 of the number of surgical masks purchased}

Source: Romania's electronic public procurement system (SEAP)

As a phenomenon specific to a demand market, generated a growing global need for such types of products, in the context in which the capacity to insure these products in the Romanian market was limited (not being domestic producers in this market) the average purchase price had an upward trend, registering in February 2020 a spectacular growth rate $(1,076 \%$ compared to January 2020), in March a doubling of the price ( $205 \%$ compared to February) and in April marking the first sign of stabilization in the market by returning to the average price recorded in the first 4 months of the year $(2.12$ lei / piece).

Again, it should be noted that the average unit price for transactions in January 2020, even if it was significantly higher than the average unit price recorded in the previous year (1.8 times), was not yet influenced by the crisis announced in this market.

This table of public procurement of surgical masks shows us a side of the impact that the COVID-19 crisis had on the public procurement processes carried out by the contracting authorities in Romania, which is characterized by a lack of prevention in terms of ensuring stocks of protection as well as poor risk management in terms of public procurement.

These data generated by the public procurement processes carried out through Romania's electronic public procurement system (SEAP) by the contracting authorities involved in the actions to combat and manage the consequences of the pandemic, were constituted as input data that were used in the process of analyzing the range of options and adopting optimal decisions to treat the selected risks.

Considering the need to equip with personal protective equipment the persons involved in actions to combat the spread of Coronavirus COVID19 and to manage its effects, possible risk avoidance or risk acceptance options may lead to consequences such as unavailability of products in the required quantity or at the appropriate time, respectively, for the inefficient use of the funds allocated to these acquisitions, with 
negative consequences on the health of its own staff or citizens, respectively on the financial capacity of the institution.

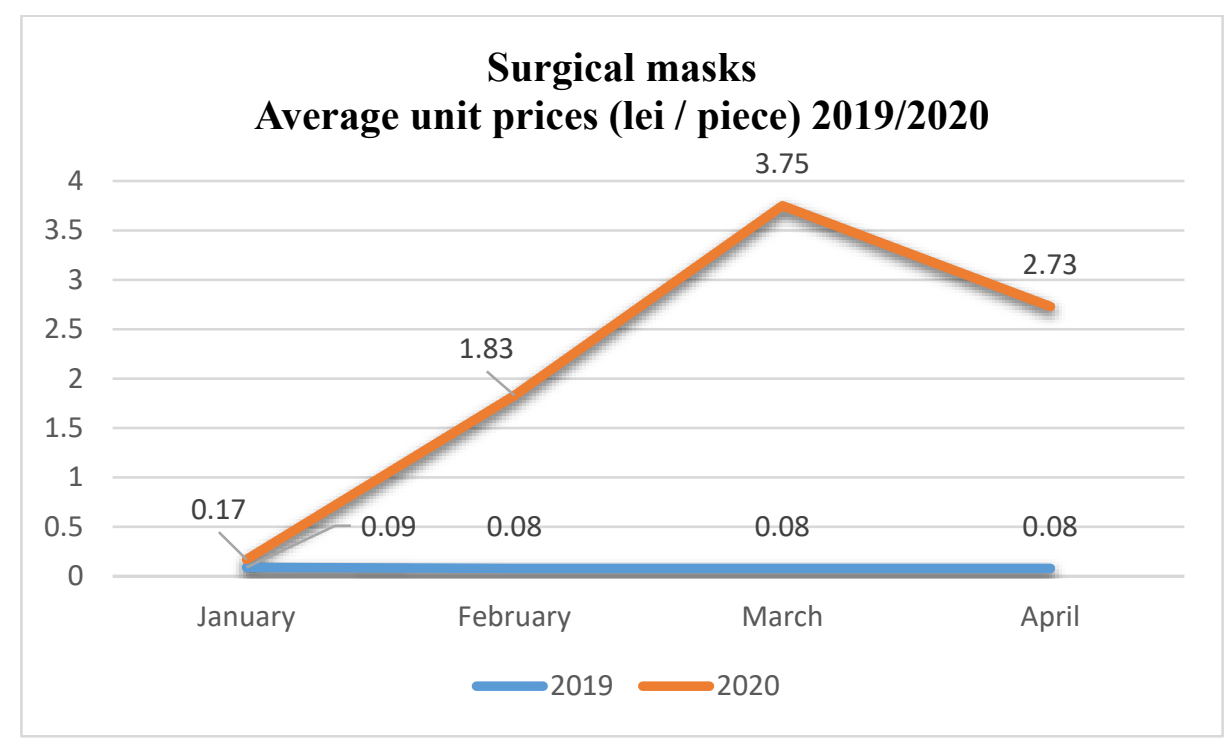

Chart 3 Comparative analysis 2019/2020 of the average unit prices for surgical mask purchases

Source: Romania's electronic public procurement system (SEAP)

Therefore, a risk treatment plan highlighted in table no. 3, appropriate for this context will be based mainly on options aimed at controlling and transferring risks and less at avoiding or accepting risks.

3.3. Options for treating with the risks specific to the processes of public procurement of protective materials in the context of an emergency situation.

As a first package of risk management measures is the one related to mitigating the consequences of the risks identified by:

$\checkmark$ Dividing the stock of products required to be purchased into batches and sequencing them through public procurement contracts with different delivery terms for each batch, leading to lower prices for the products to be delivered in the second part of contractual interval, with impact mitigation of economic risks (R.1.1) and commercial risks (R.4.1.)

$\checkmark \quad$ The granting the paying in advance, under conditions provided by the law, to the selected provider, as will lead to improving the bargaining power of the provider in relation to its competitors, followed by decreasing the internal risk of the supplier (R.3.1, R.3.2.) and commercial risks (R.4.1 and R.4.2.)

$\checkmark$ Using of Framework Agreements, with additions to the quantities of products subject to the contracting authority's plans in case of emergency, leading to a reduction in procedural times related to procurement processes and the maintenance of an adequate price of contracted products, with the impact of mitigating economic risks (R.1.1.) risks regarding the Public Procurement portfolio (R.2.1), internal risks of the supplier (R.3.1. and R.3.2.) as well as commercial risks (R.4.1, R.4.2) .

$\checkmark$ Using at the level of the contracting authority of a list of pre-selected suppliers 
(like „Qualified Vendor List”), for those products that are identified in the response plans of the contracting authority in emergency situations. The criteria on the basis of which these suppliers can be pre-selected, will be selected according to the specifics of each product. (e.g. the length of the distribution chain between the manufacturer and the contracting authority, the existence of domestic producers, the responsiveness, the product's own storage capacity, quality and safety standards, price stability, etc.). This treatment will lead to a better assessment of the contracting authority's financial effort, to reducing the administrative time required by the contracting authority's operational procedures, to conduct public procurement processes and to select the supplier, in accordance with the law, while maintaining a high level of supplier response, and as appropriate, the quality of the product supplied. This measure will have a mitigating impact on economic risks (R.1.2), portfolio risks (R.2.1.) And trade risks (R.4.1 and R.4.2.)

$\checkmark$ The use in the procurement process of a requirement regarding the presentation by the bidder of the proof of availability and possibility to reserve the stock of products subject to the future contract (at the manufacturer, logistics operator, own warehouse, etc.), measure that will have a diminishing impact of the internal (R.3.1 and R.3.2) and commercial (R.4.1. and R.4.2) risks of the future supplier.

Another package of risk management measures may be the one related to the transfer of risks through:

$\checkmark$ Segmentation of the quantity of products needed in distinct lots, which will be assigned to distinct economic operators, which will lead to a transfer of internal (R.3.1., R.3.2.) and commercial risks (R.4.1., R.4.2), between competing economic operators operating in this market segment.

$\checkmark$ Award of contracts through centralized procurement units (e.g. ONAC ${ }^{8}$ ) for part of the required quantity of products, which will lead to a transfer to this centralized procurement unit of economic risks (R.1.1, R.1.2) and of the risks regarding the public procurement portfolio (R.2.1.0).

These examples of risk treatment measures can be the starting point for improving risk management plans specific to contracting authorities involved in emergency management actions and combating their effects, such as County/Municipal Emergency Hospitals, County Emergency Inspectorates, County Police Inspectorates, etc.

\section{Directions for action on dealing risk treating related to public procurement processes carried out in the context of emergencies}

As highlighted in countless works and published articles, the COVID-19 crisis has contrasted the reduced ability of public authorities to change in the short term and to take decisions in a context of uncertainty.

According to the documents published by the contracting authorities in Romania, we find that, for the most part, they were limited to a formalized risk management, without generating risk plans that refer to concrete measures, specific to public procurement, by which to highlight the actions to be taken in case of emergencies.

\footnotetext{
${ }^{8}$ ONAC:The National Office for Centralized Procurement, whose role is to organize centralized procurement for and on behalf of the contracting authorities in Romania, for products with a significant share in the national public procurement portfolio.
} 
Therefore, the experience gained after the events that took place in Romania during January-May 2020, caused by this health crisis, shows us that on the line of change management, the contracting authority must adopt a change management appropriate and to change its attitude also in terms of the risks specific to public procurement.

The crisis triggered by the COVID-19 pandemic provided the necessary opportunity for new concrete measures, aimed at increasing the capacity for change and administrative capacity at the level of contracting authorities, in terms of managing procurement portfolios in an emergency context.

Thus, as directions of action at regional/local level we highlight at least the following:

a) developing working procedures in the field of risk management, with mandatory highlighting of risks specific to public procurement and focusing less on formal aspects of processes and more on identifying risk management measures, in the context of the legal framework on public procurement;

b) development of human resources trainings programs, carried out sectorally, focused on the initiation and management of risk management plans specific to certain categories of contracting authorities, based on workshops and case studies aimed mainly at developing identification skills, analysis, assessment and treatment of sector-specific risks related to the contracting authority;

c) updating the system and operational procedures, existing at the level of the contracting authorities involved, the actions of managing emergency situations and combating their effects, by increasing the frequency with which the risk plans (monthly / quarterly) related to public procurement of products/ services /works identified to be necessary in such situations:

d) operationalization of ex-post analyzes related to the previous public procurement processes, at the level of the contracting authority, which should provide detailed information that can be used as input data in the processes of elaboration and management of risk management plans.

As complementary measures to the above, we also propose a package of action directions at national level such as:

i) establishment and/or operationalization of central procurement units at the level of ministries that are involved in the management of emergency situations (eg Ministry of Health, Ministry of Interior, Ministry of National Defense, Ministry of Environment, etc.), at the level of which to manage specific risk management plans in the field of public procurement.

ii) implementation (procedurally) of a unitary risk management concept at the level of certain categories of contracting authorities (eg Hospitals), based on $\mathrm{EU}^{9}$ and Romanian ${ }^{10}$ guidelines as well as through guides and methodologies published in this regard;

iii) operationalization of a tertiary legislative package by National Agency for Public Procurement and /or General Secretariat of the Government, for the implementation at the level of the contracting authorities involved the actions of management of emergency situations and combating their effects (mandatory regime) of risk management plans, specific to public procurement. In this regard, it is necessary for National Agency for Public Procurement, in collaboration with the relevant institutions, to generate guidelines on the initiation and operationalization of these risk management plans, by highlighting standard risk management measures identified to be common to a certain category of contracting authorities.

\footnotetext{
${ }^{9}$ E.g.: ,Risk Assessment and Mapping Guidelines for Disaster Management”

${ }^{10}$ E.g.: „Guide to the implementation of internal control standards in public procurement management by the contracting authorities - Standard 8- Risk Management" as a supporting document for the OSGG $600 / 2016$
} 
Also, as a specific tool for risk management, we propose that at the level of certain contracting authorities, which are expected to be involved in actions to manage emergencies and combat their effects, to periodically conduct stress tests to analyze after the implementation of the above measures, the potential effects that may generate certain risks in the category of the above identified on the objectives set at the level of public procurement portfolio and on the performance indicators set at the level of the contracting authority.

\section{References}

Adroniceanu, A. (1999), Public management, Bucharest: Economic Publishing House. Ayyub, B. M. (2014), Risk Analysis in Engineering and Economics, Maryland, USA: Chapman and Hall/CRC.

Becq, B. (2006), Procurement Reform and Capacity Building: Shortcuts and Tools to Facilitate the Implementation (a 2-a ed.).

Florea-Ianc, M. M. (2010), Identifying and assessing the categories of risks associated with audited organizations, Annals of the "Constantin Brâncuşi" University of Târgu Jiu, Economy Series, Nr. 1/2010.

Grossi, G., \& Steccolini, I. (2014), Accounting for public governance, Emerald Insight, Vol 11, No.2, 86-91.

Harink, J. (1999), Excelling with E-Procurement: The Electronic Highway to Competitive Advantage, Alphen aan den Rijn, Holland: Samson.

Imbrescu, I. (2010), Elements of public management, Bucharest: Lumina Lex.

International Organization for Standardization (2009), ISO 31010 Risk management Risk assessment.

National Audit Office (2000), Supporting innovation: Managing risk in government departments, London.

National Audit Office (2004), Managing risks to improve public services, London.

Noordegraaf, M. (2015), Public Management: Performance, Professionalism and Politics, Palgrave.

The Government of Romania, (2018), Order of the General Secretariat of the Government no. 600/2018, The Government of Romania.

Vişoiu, I., \& Rusu, C. (2010), Implementation of risk management at organizational level (Application guide), Bucharest: Economic Publishing House. 